\title{
TOURISM AND LOCAL GOVERNMENTS IN HUNGARY: THE POSITION OF TOURISM IN LOCAL COUNCIL COMMITTEES OF LOCAL GOVERNMENTS
}

\author{
Tourism and local governments in Hungary
}

\author{
GÁBOR KOZMA ${ }^{1}$ GÁBOR MICHALKÓ², ZSOLT RADICS ${ }^{1}$ \\ ${ }^{1}$ University of Debrecen in Hungary, \\ Department of Social Geography and Regional Development Planning, \\ ${ }^{2}$ Geographical Institute, Research Centre for Astronomy and Earth Sciences, \\ Hungarian Academy of Sciences, Hungary
}

Mailing address: Gábor Kozma, Department of Social Geography and Regional Development Planning, University of Debrecen, Hungary, 4032 Debrecen Egyetem tér 1, tel.: +36 52 518667, fax: + 3652 518667, e-mail: kozma.gabor@science.unideb.hu

\begin{abstract}
Introduction. The objective of this paper is to investigate the position of tourism in the committee structure of the local councils of Hungarian local governments. Material and methods. The data were sourced from websites of the settlements concerned and all the results obtained statistically evaluated using the method of descriptive statistics. Results. From the data available, we can clearly determine the role of tourism in the committees of local governments, as well as the direction of changes after the 2010 election. The results also clearly identified the factors that determine the role of tourism in local council committees and the sectors that constitute the same committees with tourism. Conclusions. The role of tourism in committees of local councils is fundamentally unfavourable and the situation deteriorated after the 2010 election. The role of tourism in committees of local councils is closely related to the size of the population and the role of tourism in the given settlements.
\end{abstract}

Key words: local council, committee, tourism, Hungary

\section{Introduction}

As a result of the increasing significance of tourism, which could be observed in the past decade, local governments, both in Europe and in the United States of America pay increasing attention to this area, and they strive to create an efficient local tourism policy. This is fundamentally a manifestation of the relationships of the persons and bodies participating in the decision-making mechanism of local governments to tourism [1], and can be best characterized by the work of elected representatives and the organizations in charge of implementing their decisions [2]. Despite the fact that tourism mainly generates income for the private competitive sector and its investors also primarily come from this sector, local governments cannot afford to neglect tourism management [3, 4], since spontaneous, unplanned and uncontrolled processes do not lead to sustainable results $[5,6]$.

It is the task of local governments to designate the frameworks in which tourism can take place to the satisfaction of all stakeholders $[7,8]$, and in exchange they can receive tax revenues from the market players that are necessary for the operation of the settlement. Local tourism policy implies, on the one hand, the drawing up of concepts, strategies and programmes, and on the other hand, systematic implementation of the same [9], in which the decision-making body (elected politicians and experts) and the office in charge of enforcement, both play a role (legislation, preparing applications for grants, etc.). In addition, we should not forget about the marketing and communication either, which are indispensable for the selling of the tourism product, constituting an integral part of the local tourism policy $[10,11]$. The role and responsibility of those managing tourism is to provide a proper infrastructural, economic, legal and organizational environment for developments, to encourage ideas that fit into the strategy, and to restrict tendencies that hinder the competitiveness of tourism [12].

The role of tourism policy is important especially in large settlements, since the tourism takes place in a functional space, originally developed not primarily for the purpose of tourism, but to serve the needs of the local populations [13]. In the creation of the infra- and supra-structure necessary for the operation of tourism, special attention should be devoted to interests of the local communities, or otherwise some conflicts may emerge that can become obstacles to desirable development of tourism $[14,15,16]$. In addition to political intentions, the strengthening of the competitiveness of settlements interested in tourism may also be encouraged by favourable attitudes of local entrepreneurs (professional organizations, chambers) and the local communities (non-governmental organizations) [17]. If dialogue can be achieved with these groups, objectives of local governments related to tourism policy can be achieved much more efficiently.

In accordance with international trends, we have observed since the middle of 1990s, also in Hungary, an increasing attention paid by local governments to tourism [18, 19, 20, 21, 22, 
23]. In addition to the abovementioned international reasons, two additional facts also justify this process. On the one hand, Hungarian laws (e.g. Act CLXXXIX of 2011 on the local governments of Hungary) mention the tasks related to tourism among the compulsory duties of local governments of settlements, as well as the municipal and district governments of Budapest. On the other hand due to the decrease of central resources, local governments were increasingly forced to support the maintenance and development of tourism using their own financial resources (Tab. 1).

Table 1. The absolute value (million HUF) and the distribution (\%) of expenses related to tourism* among the sub-systems of public finances between 2006 and 2011

\begin{tabular}{|l|c|c|c|c|c|c|}
\hline & 2006 & 2007 & 2008 & 2009 & 2010 & 2011 \\
\hline $\begin{array}{l}\text { Public finances } \\
\text { (MHUF) }\end{array}$ & $71,309.2$ & $67,486.4$ & $67,360.6$ & $66,989.3$ & $68,020.6$ & $61,955.7$ \\
\hline $\begin{array}{l}\text { Central government } \\
\text { budget (\%) }\end{array}$ & 33.6 & 30.7 & 27.6 & 29.3 & 31.5 & 35.9 \\
\hline $\begin{array}{l}\text { Local government } \\
\text { budget (\%) }\end{array}$ & 66.4 & 69.3 & 72.4 & 70.7 & 68.5 & 64.1 \\
\hline
\end{tabular}

* These figures are the amounts allocated in the appropriation accounts acts for each year under F08.a: Sports and leisure time activities and services, which is a broader category than tourism alone; however, the figures are indicative of certain tendencies.

Source: appropriation accounts bills for individual years

In the case of local governments in Hungary, one of the most important decision-making bodies are local council, which, in accordance the relevant laws, are elected by local residents every four years (last elections were held in 2010, with next one due in 2014).

But in organising the work of local councils, their various committees (which partly consist of local councillors and partly outside experts) play a very important role [24, 25], for example they prepare decisions and elaborate development concepts. These committees are established by the local council after municipal elections, and there is hardly any change in their structure between elections. Despite the fact that the scope of the committees' work is often greater than can be deduced from their names, we think it stands to reason to examine to what extent tourism is present in the names of local council committees.

The importance of the research project is inherent by the fact that the reduction of the size of local councils in Hungary in 2010 (on the basis of data published by the Hungarian National Election Office, in contrast with the 25,964 persons in the period between 2006 and 2010, there are only 17,336 councillors at local governments, which represents a mere $66.8 \%$ of the previous figure) has also significantly influenced the structure of committees.

In the spirit of the above, in the course of the present study examining settlements with populations in excess of 5,000 when exploring the current situation and settlements of 10,000 and more when looking at the situation after elections, emphasis was placed on the following questions (Budapest was excluded from the study because the Municipal Assembly of Budapest does not currently have a committee responsible for tourism, and only one of the districts has such a committee):

- to what extent is tourism present in committee structures of the councils in the local governments examined;

- how did the role of tourism change after the 2010 local government elections;

- what factors influence the presence of tourism in the structures of local council or local government committees?

\section{Material and methods}

The data was sourced from the websites of the settlements concerned, which either directly included information on the committee structure of the local council, or the Rules of Organisation and Operations, available in downloadable materials, contained this information. For the purpose of analysis of the Official data, several groups were established based on the size of individual settlements: the basis for the categories were the relevant provisions of law (Act L of 2010 on the election of local councillors and mayors [25]), which specifically defined the number of local councillors who can be elected at settlements (Tab. 2). (Due to their small number, the group of settlements with populations above 50,000 was not further subdivided.)

Table 2. The number of councillors that can be elected at settlements of different sizes

\begin{tabular}{|l|c|}
\hline $5,001-10,000$ people & 8 \\
\hline $10,001-25,000$ people & 11 \\
\hline $25,000-50,000$ people & 14 \\
\hline $50,001-$ & minimum 17 \\
\hline
\end{tabular}

Source: Act L of 2010 on the election of local councillors and mayors

All the obtained results were statistically evaluated using the method of descriptive statistics (\%). The data was statistically analysed using the Statistical Package for Social Sciences (SPSS)/14.0.

\section{Results and Discussion}

Before 2010, out of the 144 local authorities examined, 43 had committee structures in which the word "tourism" was used, which represents $29.9 \%$, placing it 14 among the 42 sectors referenced in the names of committees. The changes in the committee structures after the elections of 2010 had an unfavourable effect on tourism, similarly to most other sectors: in the new situation, only 20 of the settlements with populations of 10,000 or more $(13.9 \%)$ have committees with names including the word "tourism". The rate of decrease (more 50\%) is slightly above the average, as a result of which tourism has dropped to $18^{\text {th }}$ place in the ranking of the sectors. If we extend the analysis to settlements with populations over 5,000 , the situation is slightly worse: only 30 of the 275 local governments (10.9\%) in this group have committees with reference to tourism in their names, and in terms of the relative order of the sectors, this also means the $18^{\text {th }}$ position.

The importance of the individual sectors within local councils is also reflected to some extent by whether a separate committee deals with it or the committee's scope of competence encompasses several areas (e.g. Committee of Culture and Tourism). Analysis of the situation irrespective of the sectors reveals that the decrease of the size of local councils in 2010 also brought significant changes in this respect (Tab. 3): there was a significant drop in the number of committees dedicated to single areas, the number of committees dealing with two sectors slightly decreased, and the number of committees in charge of three or more areas stagnated (in this latter case, nevertheless, an increase in the percentage can be observed). 
Table 3. The most important analysed elements of the committee structures of local councils at the settlements examined

\begin{tabular}{|l|c|c|c|}
\hline & A & B & C \\
\hline $\begin{array}{l}\text { the number and percentage of committees dealing } \\
\text { with a single sector/area }\end{array}$ & 299 & 186 & 337 \\
$(34.1 \%)$ & $(29.0)$ & $(31.1)$ \\
\hline the number and percentage of committees dealing & 375 & 253 & 412 \\
with two sectors/areas & $(42.8 \%)$ & $(39.5)$ & $(38.0)$ \\
\hline $\begin{array}{l}\text { the number and percentage of committees dealing } \\
\text { with three or more sectors/areas }\end{array}$ & 202 & 202 & 335 \\
& $(23.1 \%)$ & $(31.5)$ & $(30.9)$ \\
\hline
\end{tabular}

A - the period before the 2010 elections in settlements with a population over 10,000 persons,

B - today in settlements with a population over 10,000 persons,

C - today in settlements with a population over 5,000 persons.

Source: own data collection using the websites of the local governments concerned

The non-prioritised position of tourism within local council is also well demonstrated by the fact that among the Hungarian settlements examined, the number of committees dealing exclusively with tourism was very low (Tab. 4): both before and after the elections, there were three settlements in this group, and only one of them (Hajdúszoboszló, a city well known by foreign tourists, which has the largest outdoor aqua park in the Central Europe) had a committee dealing with tourism in both periods. In the light of the above it is hardly surprising, then, that the word "tourism" is only primarily used names of committees that have three or more areas of responsibility, a trend that was further reinforced after the 2010 elections.

Table 4. The presence of tourism in the committee structures of local councils at the settlements examined

\begin{tabular}{|l|c|c|c|}
\hline & A & B & C \\
\hline $\begin{array}{l}\text { the number and percentage of committees dealing } \\
\text { exclusively with tourism }\end{array}$ & 3 & 3 & 3 \\
$(7.0 \%)$ & $(15.0)$ & $(10.0)$ \\
\hline $\begin{array}{l}\text { the number and percentage of committees dealing } \\
\text { with one sector/area in addition to tourism }\end{array}$ & 15 & 4 & 7 \\
\hline $\begin{array}{l}\text { the number and percentage of committees dealing } \\
\text { with two or more sectors/areas in addition to tourism }\end{array}$ & $\begin{array}{c}(58.9 \%) \\
(25.1 \%)\end{array}$ & $\begin{array}{c}(65.0) \\
(23.3)\end{array}$ & $\begin{array}{c}20 \\
(66.7)\end{array}$ \\
\hline
\end{tabular}

A - the period before the 2010 elections in settlements with a population over 10,000 persons,

$\mathrm{B}$ - today in settlements with a population over 10,000 persons,

$\mathrm{C}$ - today in settlements with a population over 5,000 persons.

Source: own data collection using the websites of the local governments concerned

From among the factors determining the role of tourism in committees of local councils, two should be emphasized in particular. On the one hand, an important role is played by the size of the given settlement which - as we mentioned before - also determines the number of councillors. According to the data (Tab. 5) large settlements - striving to ensure that their structure of committees covers the largest possible number of areas - more frequently set up committees that also dealt with tourism. The elections of 2010 had the largest impact in settlements with populations between 10,001 and 25,000, and over 50,000: the role of tourism in the structure of committees significantly decreased in both brackets
Table 5. The role of tourism in committee structures in the period before (A) and after (B) the municipal elections of 2010 (the percentage of local governments that reflect tourism in the designations of their settlements in the given size bracket, \%)

\begin{tabular}{|l|c|c|}
\hline & A & B \\
\hline $5,001-10,000$ people & n.a. & 8.8 \\
\hline $10,001-25,000$ people & 25.0 & 9.4 \\
\hline $25,000-50,000$ people & 29.6 & 22.2 \\
\hline $50,001-$ & 57.9 & 26.3 \\
\hline
\end{tabular}

Source: own data collection using the websites of the local governments concerned

On the other hand, from among the factors determining the role of tourism in the committees of local councils, an important role is played by the extent of development of tourism, which is primarily due to the fact that predominantly local councils of those settlements consider setting up such committees an important task where tourism already plays a considerable role. As far as indicators of the importance of tourism are concerned despite all the problems arising in connection with it - one of the most important ones is still the number of guest nights. According to the data (Tab. 6), there is a one-directional relationship between the relative number of guest nights (per 1,000 population) and the importance of the role of tourism in the committee structure. This means that in settlements with committees that (also) deal with tourism, there is a high number of guest nights spent per 1,000 population, while at the same time, only about $25 \%$ of the settlements that record a high relative number of guest nights have committees that (also) deal with tourism. (The link between the two factors is strongest in case of settlements with a population of 50,000 and above.)

Table 6. The relationship between the role of tourism in the committee structures and the relative number guest nights (per 1,000 population) in settlements in the various size bracket, after the elections of 2010

\begin{tabular}{|l|c|c|}
\hline & A & B \\
\hline $5,001-10,000$ people & 16.7 & 30.0 \\
\hline $10,001-25,000$ people & 24.0 & 66.7 \\
\hline $25,000-50,000$ people & 25.0 & 33.3 \\
\hline $50,001-$ & 50.0 & 80.0 \\
\hline for all settlements & 25.9 & 50.0 \\
\hline
\end{tabular}

A - the percentage of settlements within the upper $1 / 3$ bracket on the basis of the number of guest nights per 1,000 population that have committees dealing with tourism

$\mathrm{B}$ - the percentage of settlements with committees dealing with tourism that are in the upper $1 / 3$ bracket on the basis of the number of guest nights per 1,000 population (\%)

Source: own data collection using the websites of the local governments concerned

The situation and status of tourism within the local government/council, as well as the treatment of this area, is well reflected by the fact which sectors deal with tourism, i.e. what other sectors are dealt with in the same committee with tourism. According to the data (Tab. 7), in this respect the role of culture can be regarded as having an outstanding importance; urban development and sports show also have high correlation factors, while religion, non-governmental sector and public procurement are in the same committee with tourism in one case each. 
Table 7. The distribution of sectors linked to tourism in the committee of local councils in settlements over 5,000 population today (the proportion of the given sector within committees also dealing with tourism, \%)

\begin{tabular}{|l|c|c|}
\hline & A & B \\
\hline Culture & 33.3 & 40.0 \\
\hline Urban development & 26.7 & 33.3 \\
\hline Sport & 26.7 & 26.7 \\
\hline Education & 20.0 & 20.0 \\
\hline Environmental protection & 16.7 & 20.0 \\
\hline Youth & 13.3 & 13.3 \\
\hline Economy & 10.0 & 10.0 \\
\hline Financial & 10.0 & 10.0 \\
\hline International & 6.7 & 10.0 \\
\hline Public safety & 6.7 & 10.0 \\
\hline City operation & 6.7 & 6.7 \\
\hline Religion & 3.3 & 3.3 \\
\hline Civil & 3.3 & 3.3 \\
\hline Public procurement & 3.3 & 3.3 \\
\hline
\end{tabular}

A - normal value;

$\mathrm{B}$ - weighted value (taking into consideration whether the given committee deals with one or two and more areas)

Source: own data collection using the websites of the local governments concerned

\section{Conclusions}

The most important findings of the study could be summarised as follows:

- The role of tourism in committees of local councils is fundamentally unfavourable, and the situation has deteriorated after the 2010 elections.

- The local governments of the districts of Budapest did not strive to establish committees that also deal with tourism.

- The role of tourism in committees of local councils is closely related to the size of the population and the role of tourism in individual settlements.

- Tourism is most frequently dealt with in the committees also responsible for culture, sports and urban development.

\section{Acknowledgements}

The publication is supported by the TÁMOP-4.2.2/B-10/ 1-2010-0024 project. The project is co-financed by the European Union and the European Social Fund.

\section{Literature}

1. Michalkó, G. (1999). The theory and practice of urban tourism ( $1^{\text {st }}$ edition). Budapest, Hungary: MTA Földrajztudományi Kutatóintézet. [in Hungarian]

2. Michalkó, G. (2007). The foundations of tourism theory ( $1^{\text {st }}$ edition). Székesfehérvár, Hungary: Kodolányi János Főiskola. [in Hungarian]

3. Maitland, R. (2006). How can we manage the tourist-historic city? Tourism strategy in Cambridge, UK, 1978-2003. Tourism Management 27(6), 1262-1273.

4. Russo, A. (2002). The „vicious circle” of tourism development in heritage cities. Annals of Tourism Research 29(1), 165-182.
5. Borg, J. \& Russo A. (2002). Planning considerations for cultural tourism: a case study of four European cities. Tourism Management 23(6), 631-637.

6. Connell, J., Page S. \& Bentley T. (2009). Towards sustainable tourism planning in New Zealand: Monitoring local government planning under the Resource Management Act. Tourism Management 30(6), 867-877.

7. Barker, M. \& Page S. (2002). Visitor safety in urban tourism environments - the case of Auckland, New Zealand. Cities 19(4), 273-282.

8. Hoffman, L., Fainstein S. \& Judd D. (Eds.) (2003). Cities and visitors - regulating people, markets, and city space. Oxford, United Kingdom: Blackwell.

9. Edwards, D., Griffin T. \& Hayllar B. (2008). Urban tourism research - developing an agenda. Annals of Tourism Research 35(4), 1032-1052.

10. Bramwell, B. \& Rawding L. (1996). Tourism marketing images of industrial cities. Annals of Tourism Research 23(1), 201-221.

11. Judd, D. (1995). Promoting tourism in US cities. Tourism Management 16(3), 175-187.

12. Chang, T., Milne S., Fallon D. \& Pohlmann C. (1996). Urban heritage tourism - the global-local nexus. Annals of Tourism Research 23(2), 284-305.

13. Ashworth, G. \& Page S. (2011). Urban tourism research: recent progress and current paradoxes. Tourism Management 32(1), 1-15.

14. Berényi, I. (2002). Theoretical and methodological questions of applied social geography. Budapest, Hungary: MTA Földrajztudományi Kutatóintézet. [in Hungarian]

15. Egedy, T., Földi Zs., Balogi A. \& Kovács Z. (2009). Budapest in the eyes of creative foreigners - the view of transnational migrants. Amsterdam: ACRE report no 7.4.

16. Snaith, T. \& Haley A. (1999). Residents' opinions of tourism development in the historic city of York, England. Tourism Management 20(5), 595-603.

17. Dredge, D. (2006). Policy networks and the local organisation of tourism. Tourism Management 27 (2), 269-280.

18. Bakucz, M. (2001). Reflections on the future development of municipal tourism - based on visitor surveys in two twinned cities. Tér és Társadalom 15(1), 131-151. [in Hungarian]

19. Hegyi, Zs. (2010). Marketing activity for reinforcing the tourism effects of Pécs2010 programme on tourism. Turizmus Bulletin 14(1-2), 44-46. [in Hungarian]

20. Michalkó, G. (1996). The possibilities of applied social geography in the research of tourism. Tér és Társadalom 10(2-3), 1-17. [in Hungarian]

21. Molnár, Cs., Kincses A. \& Tóth G. (2009). The effects of spadevelopment in East Hungary: a comparison of Hajdúszoboszló, Mezőkövesd and Orosháza. Turizmus Bulletin 13(4), 20-31. [in Hungarian]

22. Puczkó, L. \& Rátz T. (2003) Tourism in historical cities: planning and management. Budapest, Hungary: Turisztikai Oktató és Kutató Press. [in Hungarian]

23. Sudár, A. (2003). The relations of tourism and settlement development in Gödöllő. Tér és Társadalom. 17(4), 67-83. [in Hungarian]

24. Csefkó, F. (1997). Local governmental system (1 $1^{\text {st }}$ edition). Budapest-Pécs, Hungary: Dialóg Campus Kiadó. [in Hungarian]

25. Belányi, M., Csalló K., Feik Cs., Fogarasi J. \& Tábi R. (2010). Local governments $\left(1^{\text {st }}\right.$ edition). Budapest-Pécs, Hungary: HVG-ORAC Kiadó. [in Hungarian]

Submitted: September 11, 2012

Accepted: October 17, 2012 